\title{
Studi Komparatif Pelaksanaan Poligami Rasulullah Dan Pelaksanaan Poligami Pada Zaman Kekinian Menurut Inpres Nomor 1 Tahun 1991 Tentang Kompilasi Hukum Islam (Studi Kec. Mare)
}

\author{
Satriana \\ Institut Agama Islam Negeri (IAIN BONE) \\ Satriana@gmail.com
}

\begin{abstract}
Abstrak
Penelitian ini adalah penelitian lapangan dengan menggunakan study perbandingan. Sedangkan, tujuan desain penelitian adalah untuk membandingkan, meringkaskan berbagai kondisi, fenomena realitas sosial yang ada di masyarakat yang menjadi obyek penelitian, dan berupaya menarik realitas atau kenyataan yang sebenarnya mengenai bagaimana pelaksanaan perkawinan poligami yang terjadisekarang ini khususnya di Kec. Mare.Hasil penelitian menunjukkan. Poligami yang dipraktekkan di Kecamatan Mare Provinsi Sulawesi Selatan, adalah poligami (sirri) atau perkawinan yang tidak dicatatkan. Bila dipandang dari sisi agama sah karena pernikahannya dilakukan sesuai dengan tata cara pernikahan dalam Islam yaitu terpenuhinya rukun dan syarat sahnya pernikahan. Akan tetapi jika dipandang dari sisi undang-undang Negara pernikah mereka itu tidak sah karena tidak memenuhi syarat-syarat poligami dalam agama yang di syari'atkan oleh Allah swt. Faktorfaktor yang menyebabkan maraknya praktek poligami pada masyarakat Kecamatan Mare yaitu karena poligami bukan hal yang asing di lingkungan masyarakat desa mereka. Mereka tetap mempercayai bahwa poligami itu merupakan ajaran agama dan sunnah Nabi dan adanya anggapan masyarakat bahwa perkawinan tetap di pandang sah walaupun tidak dicatatkan. Yang penting sudah sesuai aturan agama. Dalam praktek poligami yang terjadi sekrang ini hanya semata-mata demi kepentingan pribadi tanpa melihat tujuan hakiki dari poligami itu sendiri, selain itu praktek poligami yang terjadi tidak memberikan sisi kebaikan atau kemeslahatan bagi pasangan yang melakukan poligami.
\end{abstract}

Kata Kunci : Studi Komparatif Pelaksanaan Poligami Rasulullah Dan Pelaksanaan Poligami Pada Zaman Kekinian Menurut Inpres Nomor 1 Tahun 1991 Tentang Kompilasi Hukum Islam (Studi Kec. Mare) 
74 | Satriana

\section{Pendahuluan}

Poligami yang marak terjadi di kalangan masyarakat, tidak semua orang mengetahui dengan jelas apa perkawinan poligami itu? Apa yang menjadi penyebab sehingga poligami terjadi dan sah secara hukum (baik menurut hukum syari'at Islam maupun perundang-undangan yang dibuat oleh negara)?

Seperti yang terjadi di Kecamatan Mare Kabupaten Bone, pelaksaana poligami sangat jauh berbeda dengan pelaksanaan poligami pada zaman rasulullah hal ini dapat dilihat dari kacamata sejarah. Rasulullah melakukan poligami dengan beberapa alasan yang sangat berat seperti demi kemaslahatan melindungi hak perempuan, dan anak yatim agar tidak terdzolimi, serta disetujia oleh para kerabat rasulullah dan istri-istrinya. Berbeda dengan pelaksanaan poligami yang terjadi di Kecamatan Mare cenderung lebih mementingkan diri pribadi (syahwat), tanpa mengindahkan aturan poligami sebagaimana yang terdapat dalam Al-Quran maupun perundang-undangan. ${ }^{135}$

Mengacu pada hukum islam (fiqh), poligami merupakan bentuk yang diperbolehkan. Mayoritas ulama memperbolehkan pernikahan poligami, dan pandangan kebolehan pernikahan poligami ini didasarkan pada ayat Al-Quran Surat al-Nisa. Namun perlu diketahui turunya ayat tersebut dilatari oleh praktik pernikahan yang dilakukan laki-laki dengan motivasi penguasaan harta anak dan atau perempuan yatim. Tidak menghendaki adanya pernikahan dengan motivasi tersebut Allah menurunkan ayat tersebut untuk menghalangi praktik pernikahan tersebut. Namun ayat tersebut kemudian dipahami sebagai sebuah dasar pembolehan praktik pernikahan pologami secara umum. Meskipun beberapa kalangan menafsirkan kebolehan dengan penekanan pada kalimat berikutnya yang menyinggung tentang keadilan yang harus dipenuhi suami, mayoritas ulama menganggap keharusan berlaku adil tidak terlalu penting mengingat keadilan merupakan hal yang sangat abstark. ${ }^{136}$

Sebenarnya perkawinan poligami tidak hanya menimbulkan rasa kekecewaan terhadap istri, tetapi juga menimbulkan rasa ketidak adilan terhadap kaum perempuan pada umumnya. keharusan berlaku adil kepada kedua istrinya sulit diwujudkan, sehingga bukanlah surga yang diperoleh tetapi akan menambah dosa disebabkan berkembangnya rasa saling curiga antara isteri pertama dengan isteri kedua. Dengan

${ }^{135}$ Asep saipuddin jahar, dkk. Hukum Keluarga, Pidana dan Bisnis, h. 30

${ }^{136}$ Asep saipuddin jahar, dkk. Hukum Keluarga, Pidana dan Bisnis, h. 30 Jurnal Al-Dustur; VOLUME 1 NO 1, DESEMBER 2018 
demikian tujuan utama membangun rumahtangga jauh dari harapan, bahkan yang dirasakan adalah timbulnya kemudharatan. ${ }^{137}$

Berdasarkan fakta tersebut penulis perlu membandingkan pelaksanaan poligami pada zaman rasulullah dan pada zaman kekinian agar masyarakat lebih mengetahui dan memiliki wawasan serta pemahaman mengenai poligami. Selain itu agar masyarakat memiliki landasan dan pertimbangan yang sesuai dan sejalan dengan syari' at islam.

\section{Rumusan Masalah}

Berawal dari latar belakang di atas maka penulis menarik kesimpulan rumusan masalah sebagai berikut:

1. Apa Hikmah Poligami rasulullah dan pelaksanaan poligami zaman sekarang menurut Inpres No. 1 Tahun 1991 tentang kompilasi hukum islam?

2. Apa yang menjadi faktor penyebab sehingga rasulullah melakukan poligami dan faktor penyebab pelaksanaan poligami pada zaman sekarang di kecamatan Mare?

\section{Defenisi Oprasional}

Untuk menghindari kesimpangsiuran dalam menafsir dan memahami maksud yang terkandung dalam judul skiripsi ini, maka penulis merasa perlu menegaskan arti kata yang terdapat dalam judul ini.

Poligami adalah perkawinan seorang suami dengan lebih dari seorang wanita. Dalam bahasa lain poligami artinya suami yang istrinya lebih dari satu. ${ }^{138}$

Perundang-undangan dalam arti formil, yaitu keputusan (beslising) tertulis yang diadakan badan-badan negara. Dalam arti materiil, yaitu peraturan tertulis yang berlaku umum dan dibuat oleh penguasa atau negara ${ }^{139}$

Perilaku Poligami, Kata "perilaku" adalah tindakan atau perilaku suatu organisme yang dapat diamati bahkan dapat dipelajari. Sedang yang dimaksud dengan "perilaku poligami" adalah suatu tindakan yang dilakukan oleh individu yang berada dalam ikatan perkawinan dikarenakan adanya sebab tertentu.

\footnotetext{
${ }^{137}$ Nurjannah Ismmail, Perempuan Dalam Pasungan, (Cet. 1: Yogyakarta; LkiS Yogyakarta, 2003), h. 328

138 Beni ahmad saebani dan Encup supriatna, Antropologi hukum, (Cet. 1: Bandung; CV PUSTAKA SETIA, 2012), h. 152.

${ }^{139}$ Ali Zaenudin, Filsafat Hukum Islam.( Jakarta : Grafindo, 2000), h. 112. Jurnal Al-Dustur; VOLUME 1 NO 1, DESEMBER 2018
} 
Berdasarkan defenisi operasional diatas maka dapat disimpulkan bahwa dalam menegakkan sistem keadilan seperti yang diajarkan oleh syari'at Islam dan serta perbandingan pelaksanaan poligami yang dilakukan rasulullah sehingga dapat diketahui tentang peelaksanaan poligami pada zaman sekarang. Selain dari pada itu dapat melakukan penalaran mengenai praktek poligami masyarakat yang dituntut memenuhi tanggung jawab yang lebih besar terhadap keluarga.

Poligami di atur berdasarkan hukum islam dengan berlandaskan pada AlQuran yang terdapat dalam QS. An-Nisa. Dan juga di atur dalam Inpres No. 1 Tahun 1991 Tentang Kompilasi Hukum Islam (KHI). Islam membolehkan poligami namun dengan beberapa pertimbangan yang cukup berat, salah satunya mampu berlaku adil, mampu berlaku adil bukan hanya mampu memberikan hak yang sama antara istri yang pertama dengan istri kedua namun masih banyak lagi.

\section{Tujuan dan Kegunaan}

Adapun tujuan penulisan sebagai berikut:

1. Untuk mengetahui Hikmah Pelaksanaan Poligami rasulullah dan pelaksanaan poligami zaman sekarang menurut inpres No. 1 Tahun 1991 tentang kompilasi hukum islam

2. Untuk mengetahui faktor penyebab sehingga rasulullah melakukan poligami dan faktor penyebab pelaksanaan poligami pada zaman sekarang di kecamatan Mare

Kegunaan penelitian ini ada secara teori dan praktis adalah sebagai berikut:

1. Secara Ilmiah yaitu sebagai informasi bagi masyarakat terkait dengan masalah poligami

2. Secara Praktisi yaitu sebagai bahan acuan dan landasan agar masyarakat lebih memahami secara mendalam sebelum melakukan tindakan poligami.

\section{Tinjauan Pustaka}

Hasil yang penulis pahami baik berupa karya tulis, skripsi, jurnal ataupun yang lain, telah banyak karya-karya yang ditemukan yang membahas persoalan poligami, tetapi tidak menutup kemungkinan untuk terus dikaji dan ditelusuri lebih dalam lagi. Banyaknya kasus yang berhubungan dengan perkawinan poligami mendorong penulis mencoba mengungkap fenomena tersebut dengan mengamati dalam praktek kehidupan pasangan poligami. 
Dengan demikian diharapkan penelitian ini tidak sama dengan yang sudah ada. Pada umumnya kajian kasus poligami sejauh pengkajian penulis hanya terbatas pada teori saja, seperti pada penulisan skripsi yang ditulis oleh Sudibyo yang berjudul "Konsep Keadilan Dalam Berpoligami menurut Hukum Islam". Sudibyo menjelaskan bahwa konsep adil dalam perkawinan poligami harus sesuai dengan apa yang ada di dalam aturan Islam serta penerapan konsep keadilan yang benar menurut Al-Qur'an dan hukum Tuhan. Menurutnya, adil di sini tidak hanya adil dalam pemberian nafkah saja tetapi juga adil terhadap pembagian terhadap cinta dan kasih sayang kepada istriistrinya seperti pembagian jatah malam, nafkah lahiriah maupun batiniah. Bukan hanya itu, adil terhadap pemberian kasih sayang kepada anak-anaknya pun harus diperhatikan yaitu dengan memberikan hak-haknya secara penuh dan tidak berbuat aniaya kepada mereka.

Begitu juga karya dari Siti Mulyani yang mengangkat tema "Poligami Dalam Perspektif Keadilan Gender" , dalam karyanya dijabarkan bahwa poligami yang dilakukan oleh suami terhadap istri adalah merupakan suatu perbuatan yang sangat merendahkan kaum perempuan karena terdapat unsur diskriminasi sosial maupun kejiwaan. Tidak hanya itu, jika dilihat dari sisi suami itu sendiri maka tampak sangat jelas unsur yang terkandung di dalamnya lebih mementingkan kepentingan pribadi ketimbang dari sisi kaum perempuan yang jelas-jelas lebih merasakan dampak dari poligami itu sendiri. Jelas di sini bahwa, kaum perempuan merasa seperti tersisihkan karena adanya sebab yang menjadi alasan-alasan bagi suami untuk berpoligami seperti yang telah disebutkan di atas.

Berbeda dengan karya-karya di atas, M. Sholihan "Poligami Dalam Perspektif Fazlur Rahman" menjelaskan bahwa Fazlur Rahman memaparkan pendapat bahwa adanya kontradiksi di antara izin untuk beristri sampai empat orang dan keharusan untuk berlaku adil kepada mereka dengan pernyataan tegas bahwa keadilan terhadap istri-istri tersebut adalah mustahil. Menurut penafsiran yang tradisional izin untuk berpoligami itu mempunyai kekuatan hukum, sedang keharusan untuk berbuat adil kepada mereka walaupun sangat penting, terserah kepada kebaikan si suami (walaupun Hukum Islam yang tradisional memberikan hak kepada kaum wanita untuk meminta pertolongan atau perceraian apabila mereka dianiaya atau dikejami oleh suami mereka).

Dari sudut pandang agama yang normatif keadilan terhadap istri yang memiliki posisi lemah ini tergantung kepada kebaikan suami, walaupun pasti akan dilanggar. Sebaliknya modernis-modernis muslim cenderung untuk mengutamakan 
keharusan untuk berbuat adil tersebut, bahwa perlakuan adil tersebut adalah mustahil, mereka mengatakan bahwa izin untuk berpoligami itu hanya untuk sementara waktu dan tujuan tertentu saja.

Beliau memang membenarkan pendapat di atas bahwa izin berpoligami merupakan hukum, sedang sanksinya adalah untuk mencapai ideal moral yang harus diperjuangkan masyarakat karena poligami itu tidak dapat dihilangkan begitu saja. Dari karya-karya di atas maka dapat diambil kesimpulan bahwa orang yang melakukan poligami tidak mudah, di dalamnya terdapat ketentuan-ketentuan yang harus dijalankan. Serta banyak kontradiksi yang terjadi tentang hal tersebut, dan hal inilah yang ingin penulis bahas lebih lanjut karena perkawinan poligami masih belum ada pemecahan yang ada khususnya praktek di lapangan.

Hal inilah yang membuat peneliti mencoba menggali kembali tentang poligami, meskipun telah banyak pula para peneliti yang mengangkat tema di atas. Sedikit berbeda dengan karya-karya ilmiah lainnya disini penulis mengemukakan Perbandingan poligami pada zaman rasul dan pada zaman sekarang dan penelitian secara lapangan, yang lebih terperinci secara utuh berdasarkan fakta yang ada.

\section{Kerangka pikir}

Berdasarkan uraian yang telah dikemukakan sebelumnya, maka pada bagian ini diuraikan kerangka berpikir yang dijadikan landasan berpikir dalam melaksanakan penelitian. Pada dasarnya kerangka berpikir akan menjelaskan secara teoritis hubungan antar variabel (variabel independen dan dependen) yang akan diteliti. Adapun kerangka pikir yang dimaksud, adalah sebagai berikut:

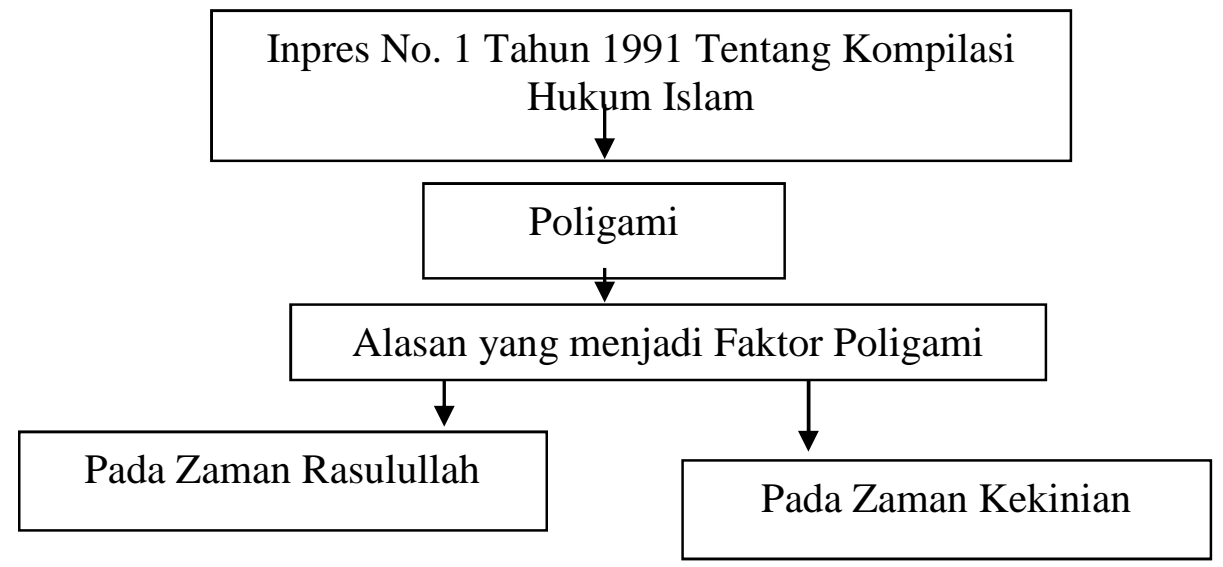

Bagan 1.1 Kerangka Pikir

Jurnal Al-Dustur; VOLUME 1 NO 1, DESEMBER 2018 
Dalam bagan diatas dapat dijelaskan bahwa poligami merupakan ikatan perkawinan yang salah satu pihak (suami) mengawini beberapa (lebih dari satu) istri dalam waktu yang bersamaan. Ringkasnya, poligami adalah perkawinan antara satu pria dengan lebih dari satu perempuan sebagai isteri-isterinya. Nama lain dari poligami yaitu poligini.

Sedangkan menurut hukum islam, poligami telah di atur dalam Al-Quran surah an-Nisa ayat 3, sebagaiman di jelaskan bahwa "Dan jika kamu takut tidak akan dapat berlaku adil terhadap (hak-hak) perempuan yang yatim (bilamana kamu mengawininya), maka kawinilah wanita-wanita (lain) yang kamu senangi:dua,tiga, atau empat. Kemudian jika kamu takut tidak akan dapat berlaku adil, maka (kawinilah) seorang saja atau budak-budak yang kamu miliki. Yang demikian itu adalah lebih dekat kepada tidak berbuat aniaya."

Poligami pada masa Rasulullah saw, dijadikan sebagai cerminan poligami dalam Islam. Pada dasarnya alasan Nabi Muhammad berpoligami bersifat mulia, yakni untuk menolong janda-janda dan anak yatim untuk "berjuang di jalan Allah" dan beliau mengamalkan monogami lebih lama daripada poligami. Sedangkan dalam konteks sekarang, alasan poligami pada umumnya adalah syahwat. Hal tersebut dapat dilihat dari banyaknya persoalan kehidupan yang rumit, kemiskinan, ketidakadilan, laki-laki justru memikirkan poligami.

\section{Metode Penelitian}

\section{Jenis Dan Pendekatan Penelitian}

Penelitian ini adalah penelitian lapangan dengan menggunakan study perbandingan. Sedangkan, tujuan desain penelitian adalah untuk membandingkan, meringkaskan berbagai kondisi, fenomena realitas sosial yang ada di masyarakat yang menjadi obyek penelitian, dan berupaya menarik realitas atau kenyataan yang sebenarnya mengenai bagaimana pelaksanaan perkawinan poligami. ${ }^{140}$

Jenis pendekatan dalam penulisan ini adalah pendekatan yuridisnormatif dan normatif-empiris: Pendekatan yuridis normatif adalah pendekatan yang dilakukan berdasarkan bahan hukum utama dengan cara menelaah teori-teori, konsep, konsep, asas-asa hukum serta peraturan peeundang-undangan yang berhubungan dengan penelitian ini. Pendekatan

\footnotetext{
${ }^{140}$ Burhan Mungim, Peneltian Kualitatif: Komunikasi, Ekonomi, Kebijakan Publik, dan Ilmu Sosial Lainny, (Jakarta: Prenada Media Group, 2008), h. 68.

Jurnal Al-Dustur; VOLUME 1 NO 1, DESEMBER 2018
} 
$\mathbf{8 0}$ | Satriana

normatif-empiris adalah penggabungan antara pendekatan hukum normatif dengan adanya penambahan berbagai unsur empiris (kenyataan). Metode penelitian normatif-empiris mengenai implementasi ketentuan hukum normatif (undang-undang) dalam aksinya pada setiap peristiwa hukum tertentu yang terjadi dalam suatu masyarakat.

2. Lokasi penelitian

Dalam penelitian ini penulis memilih lokasi di Kecamatan Mare Kabupaten Bone, Sulawesi Selatan. Alasanya memilih lokasi penelitian ini karena merupakan salah satu terjadinya perkawinan poligami dan peneliti menemukan adanya kasus praktik perkawinan tersebut.

3. Data dan Sumber Data

Data dan Sumber data dalam penelitian adalah subjek dari mana data diperoleh. ${ }^{141}$ Adapun yang menjadi sumber data dalam penelitian ini adalah sebagai berikut:

a. Data primer

Data primer merupakan data yang diperoleh langsung dari sumber pertama. ${ }^{142}$ Data yang diperoleh langsung dari orang yang melakukan poligami, beserta dari keluarga terdekat, dan masyarakat setempat di Kec. Mare Kab. Bone.

b. Data Sekunder

Data sekunder mencakup dokumen-dokumen resmi, buku-buku, hasil penelitian yang berwujud laporan. dalam penelitian ini akan menggunakan data sekunder sebagai berikut:

1) Kajian pustaka dan dokumentasi, yaitu mengumpulkan karya-karya yang diperkirakan dapat mendukung penelitian ini, yaitu karya-karya yang memberikan informasi tentang perkawinan poligami secara umum.

2) Wawancara, yaitu pengumpulan data dimana penulis mengadakan tanya jawab secara langsung dengan sumber data terkait. Wawancara akan dilakukan terhadap pelaku maupun orang terdekat seperti,

\footnotetext{
${ }^{141}$ Suharsimi Arikunto, Prosedur Penelitian Suatu Pendekatan Praktek, (Cet. XII; Jakarta: PT Rineka Cipta, 2002), h. 107.

${ }^{142}$ Amiruddin dan Zainal Asikin, Pengantar Metode Penelitian Hukum, (Cet. 1; Jakarta: PT. Grafindo Persada, 2004), h. 30
} 
keluarga, tetangga, maupun pihak-pihak yang mengetahui praktik perkawinan poligami.

3) Observasi, yaitu peneliti mengamati apakah benar ekspresi yang diperlihatkan subyek penelitian sesuai dengan respon verbal yang diberikannya. ${ }^{143}$ Lebih lanjut menurut Patton hasil observasi menjadi data yang penting karena :

a) Peneliti akan mendapatkan pemahaman lebih baik tentang konteks hal yang diteliti atau terjadi.

b) Observasi memungkinkan peneliti untuk bersikap terbuka, berorientasi pada penemuan daripada pembuktian, dan mempertahankan pilihan untuk mendekati masalah secara induktif. Dengan berada dalam situasi lapangan yang nyata, kecenderungan untuk dipengaruhi berbagai konseptualisasi tentang topik yang diamati akan berkurang.

c) Observasi memungkinkan peneliti memperoleh data tentang halhal yang menyangkut penelitian, dan karena berbagai sebab tidak diungkap oleh informan secara terbuka dalam wawancara, seperti kegiatan informan sehari-hari, hubungan informan dengan pasangannya, keadaan rumah, dan lingkungan tempat tinggal dan lain sebagainya.

\section{Instrumen Penelitian}

Intrumen penelitian merupakan alat yang digunakan dalam pengumpulan data. Dalam penelitian ini akan menggunakan alat yaitu daftar pertanyaan, recorder dari handphone dibantu alat tulis lainnya, kemudian dibuatkan transkripnya dengan mengubah hasil wawancara tersebut dari bentuk rekaman menjadi bentuk tertulis. ${ }^{144}$

5. Tekhnik Pengumpulan Data

Tekhnik yang digunakan untuk mengumpulkan data dalam penelitian ini dengan tekhnik wawancara. Wawancara adalah percakapan dengan maksud tertentu. Percakapan itu dilakukan oleh dua pihak, yaitu pewawancara (interviewer) yang mengajukan pertanyaan dan terwawancara (interviewer)

\footnotetext{
${ }^{143}$ Amiruddin dan Zainal Asikin, Pengantar Metode Penelitian Hukum, h. 30

${ }^{144}$ Muhammad Teguh, Metodologi Penelitian Ekonomi Teori dan Aplikasi, (Ed.1-3;Jakarta: PT.RajaGrafindo Persada, 2005), h. 136-137.
}

Jurnal Al-Dustur; VOLUME 1 NO 1, DESEMBER 2018 
82 | Satriana

yang memberikan jawaban atas pertayaan. ${ }^{145}$ Wawancara yang dilakukan bertujuan untuk mendapatkan keterangan atau penjelasan langsung dari narasumber terkait dengan obyek penelitian.

Wawancara yang dilakukan dalam penelitian ini dapat diuraikan sebagai berikut: Wawancara terstruktur atau biasa disebut teknik wawancara mendalam. Dalam penelitaian ini yang akan di wawancarai adalah masyarakat yang melakukan poligami, Wawancara bebas atau wawancara tidak terstruktur. Wawancara ini dilakukan dimana peneliti tidak menggunakan pedoman wawancara yang telah tersusun secara sistematis dan lengkap untuk pengumpulan datan. ${ }^{146}$

6. Teknik Analisis Data.

Dalam menganalisis data, penulis menggunakan analisis kualitatif. Analisis kualitatif adalah upaya untuk mengungkap makna dari data penelitian dengan cara mengumpulkan data sesuai dengan klasifikasi tertentu. Penulis menggunakan analisis kualitatif dengan tahapan sebagai berikut:

c. Pengumpulan data lapangan yakni dengan mengumpulakan data yang ditemukan dilapangan yang merupakan data kasar.

d. Reduksi data adalah prosese memilih atau menyederhanakan, mengabstraksikan dan mentranspormasikan data kasar yang baru dari lapangan. $^{147}$

e. Penyajian data merupakan sekumpulan informasi yang tersusun secara sistematis yang kemungkinan adanya penarikan kesimpulan. ${ }^{148}$

Verifikasi data yakni penarikan kesimpulan akhir penelitian

\footnotetext{
${ }^{145}$ Lexy J. Moleong, Metodologi Penelitian Kualitatif, Ed. Revisi, (Cet. 22; Bandung: PT Remaja Rosdakarya, 2004), h. 189.

${ }^{146}$ Sugiono, Metode Penelitian Pendidikan Pendekatan Kuantitatif Dan Kualitatif, h. 233.

${ }^{147}$ Muhammad tholchah Hasan, dkk Metode Penelitian Kualitatif tinjauan teoritis dan praktis, (Cet. 3 Surabaya, Visipress Media, 2009), h. 183.

${ }^{148}$ Muhammad tholchah Hasan, dkk Metode Penelitian Kualitatif, h. 182.

Jurnal Al-Dustur; VOLUME 1 NO 1, DESEMBER 2018
} 


\section{HasiL Penelitian}

\section{Hikmah Pelaksanaan Poligami Rasulullah dan Pelaksanaan Poligami Zaman Sekarang Menurut Inpres No. 1 Tahun 1991 Tentang Kompilasi Hukum Islam}

Tidak sedikit orang yang salah memahami praktik poligami Nabi Muhammad saw, ada anggapan Nabi melakukan poligami dengan tujuan sebagaimana yang di lakukan oleh banyak orang, yakni untuk memenuhi tuntutan biologis atau hanya untuk memuaskan hasrat seksualnya. Pada umumnya memang poligami dilakukan untuk tujuan-tujuan biologis semata. Kekeliruan paham ini perlu diluruskan, terutama karena praktik poligami Nabi seringkali dijadikan dalil pembenaran bagi kebolehan poligami dalam masyarakat Muslim. Untuk dapat memahami makna poligami Nabi secara benar, seseorang terlebih dahulu harus mampu memahami dan menghayati perjalanan hidup pribadi Nabi Muhammad saw. ${ }^{149}$ data sejarah yang pernah ada berkenaan dengan poligami Nabi dijadikan bukti tudingan tudingan tersebut sebagaimana yang ditulis oleh Sufyan Raji Abdullah yang juga mengutip dari kitab Syubhat wa abathil 'ala Ta'addudi Zaujatirraul karangan Muhammad Ali Shobuni memaparkan jumlah Istri istri Nabial:

\section{a. Khodijah bintiKhuwalid}

Beliau mendampingi Raulullah selama 15 tahun sebelum diutusnya nabi muhammad menjadi Rasulullah dan selama 10 tahun setelah kerasulan Nabi. Rasulullah Menikah dengan Khodijah ketika usia 40 tahun sedang nabi sendiri saat itu berusia sangat muda yakni 25 tahun dengan mas kawin 20 unta betina yang masih muda .Selama pernikahan beliau dikaruniai dua anak laki laki yaitu Hasyim dan Abullah dan empat anak perempuan yaitu Zainab, Ruqayyah, ummi kultsum dan Fatimah Az-Zahra. Beluai Wafat pada usia 65 tahun tiga tahun sebelum nabi Hijrah.

\section{b. Sauda binZam`ah}

Setelah Khodijah berpulang ke rahmatullah Nabi menikah dengan dengan saudah Binti Zam'ah Janda Sakra bin Amr, saat itu sudah berusia berusia 55 tahun dan dia juga termasuk perempuan yang

${ }^{149}$ SufyanRajiAbdullah,PoligamidanEksistensinya(Bekasi:PustakaArRiyadh,2004),h.106. 
84 | Satriana

beriman yang berhijrah dengan nabi karena memeluk Agama Islam. Dia mengalami penderitaan dan menanggung penderitaan yang sangat berat karena keislamannya, sehingga ia dan suaminya memutuskan untuk berhijrah ke Euthopia, dan semua anggota keluarganya semakin marah dengan sikapnya yang meninggalkan mekkah, setelah kembali ke Euthiopia suaminya berpulang ke Rahmatullah sehingga ia hidup sendirian di Kota Mekkah tanpa ada anggota keluarganya yang menolong dan membantu, jika ia pulang kekeluarganya setelah kepergian suaminya maka pasti dia akan disiksa dan bahkan dibunuh oleh mereka.

Ketika Rasulullalh mengetahui situasi dan kondisi yang sedang dialaminya, dan karena mempertimbangkan pendiriannya yang teguh terhadap islam, serta karena kekhawatiran Nabi terhadap kondisi Saudah atas perlakuan keluarganya, Maka Rasulullah mempunyai inisiatif melamarnya guna menjamin keselamatan hidupnya dengan dua $\operatorname{alasan}^{150}$ :

1) Untuk menggantikan posisi suaminya yang beriman, dan karena pendiriannya yang teguh terhadap Islam serta karena memuliyakannya

2) Pernikhan ini diharap melunakkan hatikaumnya yaitu Bani 'Adb Syam yang memusuhi Rasulullah dan Bani Hasyim, dan mereka menerima kebaikan Rasulullah sehingga permusuhan dan pertentangan terminimalisir dengan berbondong-bondong nya pembesar Kaum Abd Syams. Saudah tinggalbersama Nabi selama 5tahun.

\section{c. Aisyah binti AbuBakar}

Nabi menikahi aisyah setelah wafatnya Saudah binti Zam'ah, kewafatan Abu Tholib serta Istri Pertamanya yakni Khodijah binti Khuwailid memberikan dampak yang cukup besar bagi jiwa Rasulullah. Meninggalnya paman beliau dan istri pertamyanya membuat posisi Nabi dihadapan penduduk Mekkah menjadi lemah, oleh sebab itu Nabi kerap mengadulan problematikanya kepada Allah

${ }^{150}$ SufyanRajiAbdullah,PoligamidanEksistensinya, h.107. Jurnal Al-Dustur; VOLUME 1 NO 1, DESEMBER 2018 
SWT yang pad Akhirnya Allah memberikan Petunjuk kepad Nabi supaya menjalin hubungan nasab dan kemertuaan dengan salah satu Suku Quraisy. Lalu Nabi pun memilih Abu Bakar yang juga merupakan keturunan suku Quraisy, siapa yang tidak tahu kedudukan AbuBakar? Dikaumnya beliau adalah pemimpin yang dimulyakan, kaya, baik kuat, adil terhadap kaumnya.

Kemudian Nabi berkeinginan untuk memperkuat tali persaudaraan yang agung itu dengan melamar putrinya yang bernama Aisyah. Rasulullah mengakui kecerdasan, kepandaian, kegeniusan, kepintaran dan keluhuran budi pekerti Aisyah. Dan diantar Istri Istri nabi yang Lain, Aisyah adalah satu satunya istri yang masih Gadis ketika dinikahibeliau.

\section{d. Hafsah binti Umar binKhotab}

Dia adalah Janda bin Khunais bin Hidzafah Al-Anshari, suaminya adalah orang yang banyak membantu Rasulullah berperang dijalan Allah sampai pada akhirnya gugur pada pertempuran di perang Badar. Ketika Rasulullah mengetahui keadaan tersebut, beliau merasa simpati danmerasa terpanggil untuk menghibur kesedihannya. Lalu beliau melamar dan menikahinya, sebagaibentuk penghormatan dan penghormatan terhadap suaminya yang gugur dimedan pertempuran untuk mempertahankan islam, serta mempertimbangkan kedudukan ayahnya yang terhormat, ayahnya adalah orang ke2 setelah Abu Bakar.

Hafsah juga termasuk istri Rasulullah yang banyak

meriwayatkan Hadist dari Rasulullah, dan ia juga menjadi tempat bertanya oleh para sahabat tentang masalah masalah agama terutama masalah kewanitaan. Dalam kondisinya yang lemah dan menyedihkan, Hafsah bukanlah perempuan yang cantik dan menarik, Hafsahberusialanjutdanjanda,sementaraRasulpadatahunke3Hijriyahsaa titu berusia 55 tahun.

\section{e. Zainab bintiKhuzaimah}

Zainab Adalah wanita mujahidah fisabilillah yang ikut mengurus dan merawat para mujahid yang terluka pada perqng badar. Suaminya Ubaidah bin Haritsb bin Abdu; Muthallib adalah seorang 
86 | Satriana

Pejuang sejati yang sangat pemberani beliau meninggal pada awal peperangan Badar.

Ketika suaminya Syahid berperang, zainab bertugas merawat para tentara muslim yang terluka pada perang Badar, syahidnya suaminya tidak menyurutkan niatnya untuk terus merawat dan mengobati para tentara yang terluka pada perang badar tersebut kegigihan dan ketabahannya mampu mengatasi semua rasa duka dan suka yang dihadapinya, ia terus merawat dan mengobati tentara yang terluka sampai Allah memberikan kemenangan.

Ketika Rasulullah mengetahui bahwa suaminya Syahid meninggal dalamperang tersebut, dan ia adalah wanita yang sangat tinggi ruh Jihadnya, sabar, ikhlas, dan wanita yang amanah, sedang tidak ada lagi orang yang mencarikannya nafkah setelah suaminya meninggal, maka akhirnya rasulullah meminangnya dan menikahinya yang saat itu zainab berusia 60 tahun dan zainab tinggal bersama rasulullah selama 2 tahun sebelum akhirnya dia wafat.

\section{f. Ummu Salamah Hindun binti Abu Umayyahal- Makhzumiyyah}

Dia adalah janda dari seorang syahid bernama Abu Salamah Abdullah bin Abdul Asad yang mana dia adalah anak paman Nabi dan Saudara sepersusuan. Abu Salamah gugur pada perang Uhud untuk melawan Bani Asadatas seruan Nabi sampai pada akhirmya ia wafat dalamsebuahpertempuran.

Dan setelah masa iddah Ummu Salamah, Rasulullah yang pada saat itu berusia 57 melamarnya dengan menyuruh seseorang utusan untuk datang kepadanya, saat itu Ummu salamah mempunyai 4 orang anak dari suaminya terdahulu yakni Barra, Salamah,Amrah danDurrah.

\section{g. Zainab bintiJahsy}

Nabi menikahi Zainab binti Jahsy Al-Asadiyah, anak peremuan bibinya, yaitu Umayyah binti Abdul; Muthalib, istri yang dicerai oleh anak angkatnya, seorang budak yang telah dimerdekakannya yaitu zaid bin Haritsah bin Syarahbil.

Ini bermula dari keinginan nabi menikahkan anak angkatnya, Jurnal Al-Dustur; VOLUME 1 NO 1, DESEMBER 2018 
Zaid dengan anak perempuan bibinya dari bangsa Arab dan keturunan Bani Hasyim, tetapi zainab tidak mau dengan alasan pengagungannasab yang melekat pada dirinya dan menganggap“rendah"zaid. Setelah turun surat Al-Ahzab :36 Zainab berubah pikiransan berkata pada nabi "saya mau melaksannakan perintah anda dan silahkan anda melakukanapa yang anda inginkan”.

Setelah pernikahan itu Zaid mulai merasakan sesuaty yang membuatnya susah, zainab sering berkata kasar kepada zaid dikarenakan Nasab yang dimiliki Zainab, sampai kemudian zaid membencinya dan meminta izin pada Rasulullah untuk menceraikan zainab,setelah bebrapakali meminta izin akhirnya Rasulullah pun memberikan Izin. Dan rasulullah mngetahu setelah perceraian ini Allahakan memerintahkan pada Nabi untuk menikahi zainab dengan tujuan menghapus bid'ah yang bekembang pada saat itu bahwasanya seseorang tidak diperbolehkan menikahi istri yang telah diceraikan oleh anak angkatnya karena status hukum anak angkat dimata mereka sama kedudukannya dengan anak kandung.

Dan bersaan dengan itu turunlah surat al-Ahzab :37:

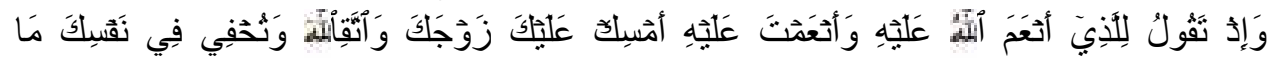

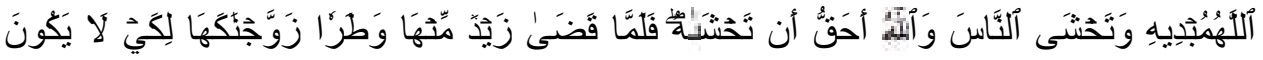

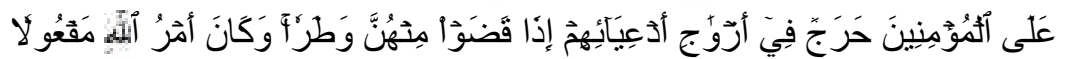

Terjemahan :

Dan (ingatlah), ketika kamu Berkata kepada orang yang Allah Telah melimpahkan nikmat kepadanya dan kamu (juga) Telah memberi nikmat kepadanya: "Tahanlah terus isterimu dan bertakwalah kepada Allah", sedang kamu menyembunyikan di dalam hatimu apa yang Allah akan menyatakannya, dan kamu takut kepada manusia, sedang Allah-lah yang lebih berhak untuk kamu takuti. Maka tatkala Zaid Telah mengakhiri keperluan terhadap Istrinya (menceraikannya), kami kawinkan kamu dengan dia supaya tidak ada keberatan bagi orang mukmin untuk (mengawini) isteri-isteri anak-anak angkat mereka, apabila anak-anak angkat itu Telah menyelesaikan keperluannya daripada isterinya. dan adalah ketetapan Allah itu pasti terjadi. 
$\mathbf{8 8}$ | Satriana

Ayat tersebut menjelaskan bahwa adanya perintah pada nabi untuk menikahi zainab dan menentang bangsa Arab dengan pernikahan ini.

\section{Kesimpulan}

pembahasan temuan penelitian tentang Studi Komparatif Pelaksanaan Poligami Rasulullah Dan Pelaksanaan Poligami Pada Zaman Kekinian Menurut Inpres Nomor 1 Tahun 1991 Tentang Kompilasi Hukum Islam (Studi Kec. Mare), maka dapat disimpulkan sebagai berikut:

1. Poligami yang dipraktekkan di Kecamatan Mare Provinsi Sulawesi Selatan, adalah poligami (sirri) atau perkawinan yang tidak dicatatkan. Bila dipandang dari sisi agama sah karena pernikahannya dilakukan sesuai dengan tata cara pernikahan dalam Islam yaitu terpenuhinya rukun dan syarat sahnya pernikahan. Akan tetapi jika dipandang dari sisi undang-undang Negara pernikah mereka itu tidak sah karena tidak memenuhi syarat-syarat poligami dalam agama yang di syari'atkan oleh Allah swt. Dalam hal ini penulis ambil simple Kompilasi Hukum Islam di Indonesia (KHI) sebagai contoh untuk umat Islam di selatan Thailand tahu Undang-undangnya, sebab Kopilasi Hukum Islam di selatan Thailand tidak ada undang-undang tertulis. Seorang lelaki mempunyi dua atau tiga bahkan empat orang isteri. Tetapi jika kamu khawatir tidak akan mampu berlaku adil maka nikahhilah seorang saja.

2. Faktor-faktor yang menyebabkan maraknya praktek poligami pada masyarakat Kecamatan Mare yaitu karena poligami bukan hal yang asing di lingkungan masyarakat desa mereka. Mereka tetap mempercayai bahwa poligami itu merupakan ajaran agama dan sunnah Nabi dan adanya anggapan masyarakat bahwa perkawinan tetap di pandang sah walaupun tidak dicatatkan. Yang penting sudah sesuai aturan agama.

\section{Implikasi}

1. Kepada para pelaku poligami dan masyarakat setempat:

a. Bersikap dan bertindak adil secara fisik, psikis, ekonomi dan seksual secara ideal, tetapi jika tidak bisa, berikan kebebasan memilih bagi isteri terdahulu apakah mau tetap tinggal dengan suami yang berpoligami atau memilih hidup sendiri. 
b. Anggapan poligami sebagai sunnah Nabi saw., tidak dapat dijadikan patokan maupun contoh karena perkawinannya berisi misi perjuangan, politik, perlindungan, dan bukan karena seks semata.

2. Kepada aparat pemerintah setempat; perlu adanya penyuluhan mengenai arti penting sebuah perkawinan agar antara suami istri benar-benar memahami hak-hak dan kewajibannya dalam sebuah rumah tangga demi terwujudnya tujuan perkawinan meskipun itu keluarga yang berpoligami.

3. Kepada masyarakat umum; sebaiknya menjauhi pernikahan poligami karena dilihat dari sisi realitas, aspek negatif poligami lebih besar dari pada aspek positifnya.

\section{Referensi}

A. Sumpeno, dkk., Kritik PoligamidalamKompilasiHukum Islam, dalamIstiqro", Volume 3, No. 1, 2004, Jakarta: Depag RI, 2004

Abdul Rahman Ghozali, Fiqh Munakahat Cet. IV; Jakarta: Kecana, 2010

al-Qurtûbiy, al-Jamiee al-Bayân li Ahkâm al-Qureên, juz V, Beirut: Dâr al-Fikr, tt.

Ani Ferial, Chiken Soup for the Moslem-Membina Keluarga Sakinah Yogyakarta: Media Abadi, 2005

Anshary, Hukum perkawinan di Indonesia, Cet. 1; Yogyakarta: Pustaka Pelajar, 2010 Departemen Agama RI, Al-Qur'an dan Terjemahannya.

Arikunto Suharsimi, Prosedur Penelitian Suatu Pendekatan Praktek,Cet. XII; Jakarta: PT Rineka Cipta, 2002

Ayyub Hasan Syaikh, Fikih Keluarga, panduan membangun keluarga sakinah sesuai syariat. Cet. V; Jakarta: Pustaka al-Kautsar, 2008

Hamdani, Risalah Nikah (Hukum Perkawinan Islam). Jakarta : Pustaka Amani. 2001

Hasan tholchah Muhammad, dkk Metode Penelitian Kualitatif tinjauan teoritis dan praktis, Cet. 3 Surabaya, Visipress Media, 2009 
90 |Satriana

Hazairin, Hukum Kewarisan Bilateral Menurut Qur'an dan Hadis, Cet. VI, (Jakarta: PT. Tinta Mas, 1982

Ismail Nurjannah, Perempuan Dalam Pasungan,Cet. 1: Yogyakarta; LkiS Yogyakarta, 2003.

J Lexy. Moleong, Metodologi Penelitian Kualitatif, Ed. Revisi, Cet. 22; Bandung: PT Remaja Rosdakarya, 2004

jahar saipuddin Asep, dkk. Hukum Keluarga, Pidana dan Bisnis, Cet, 1: Jakarta; KENCANA PRENAMEDIA GROUP, 2013.

Karim Hilmi Farhat Ahmad, PoligamiBerkahatauMusibah? Jakarta: Senayan, 2007

Labib, Pembelaan Ummat Muhammad, t.c. t.tp. CV Bintang Pelajat, 1986

Mungim Burhan, Peneltian Kualitatif: Komunikasi, Ekonomi, Kebijakan Publik, dan Ilmu Sosial Lainny, Jakarta: Prenada Media Group, 2008

${ }^{1}$ Musdah Mulia, Pandangan Islam Tentang Poligami Jakarta: LKAJ The Asia Foundation, 1999

Republik Indonesia, UU No.1 Tahun 1974Tentang Perkawinan

Saebani Ahmad Beni dan supriatna Encup, Antropologi hukum, Cet. 1: Bandung; CV PUSTAKA SETIA, 2012.

Shihab Quraish, Secerca Cahaya Ilahi, Cet. 1; Bandung: PT Mizan Pustaka, 2007 Simanjuntak, Hukum Perdata Indonesia, Cet. 1: jakarta; PRENADAMEDIA GROUP, 2015.

Slamet Abidin dan Aminuddin, Fiqih Munakahat Bandung: Pustaka Setia, 1999 
SufyanRajiAbdullah,PoligamidanEksistensinyaBekasi:PustakaAr-Riyadh,2004

Teguh Muhammad, Metodologi Penelitian Ekonomi Teori dan Aplikasi,Ed.13;Jakarta: PT.RajaGrafindo Persada, 2005

Wawancara dengan Bapak ABD, Warga Kecamatan Mare Kabupaten Bone, Tanggal 2 Juni 2018.

Wawancara dengan Bapak LJ, Warga Kecamatan Mare Kabupaten Bone, Tanggal 2 Juni 2018.

Zaenudin Ali, Filsafat Hukum Islam. Jakarta : Grafindo, 2000. 